
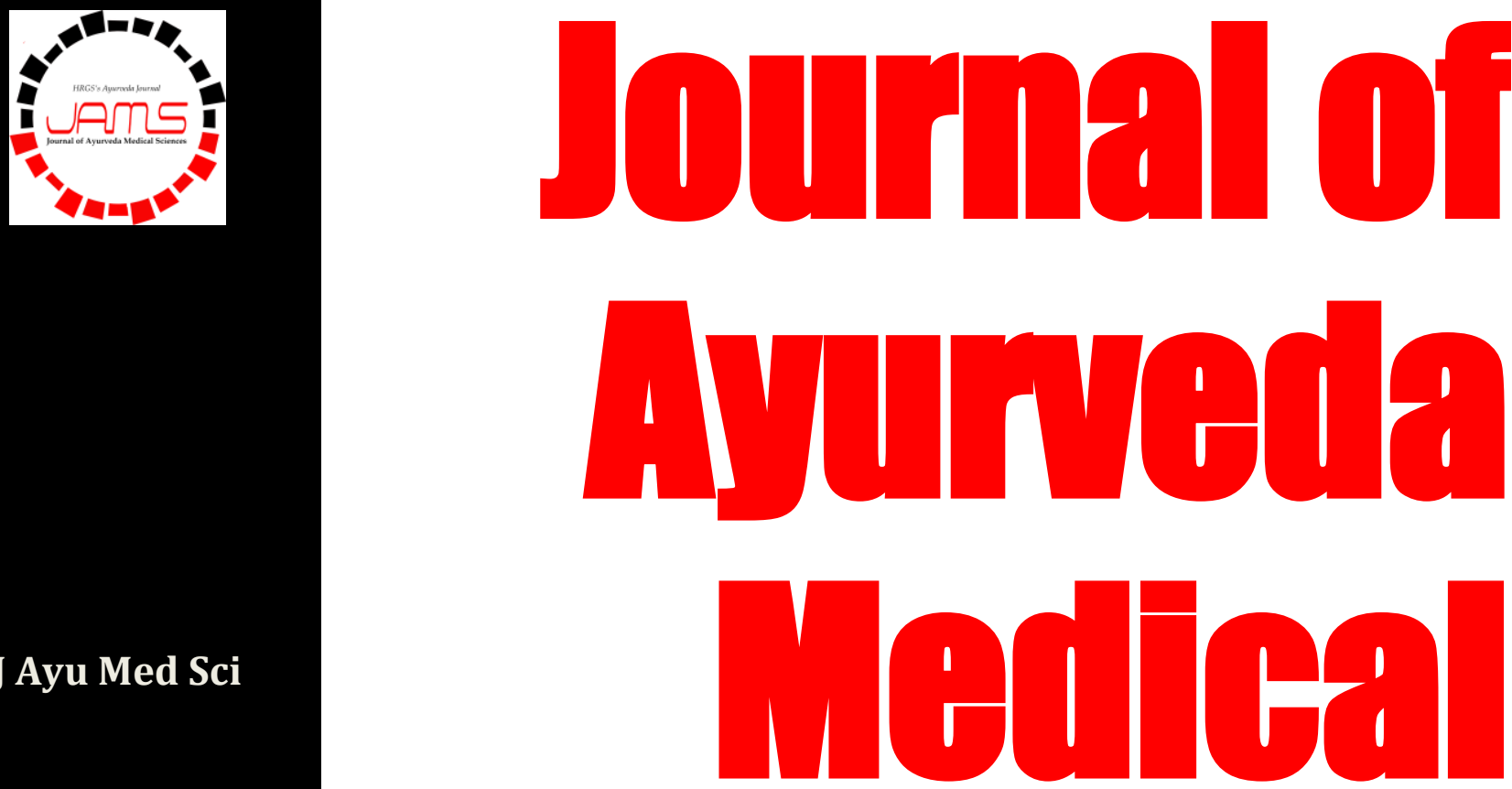

Quarterly Journal for

Rapid Publication

of Researches

in Ayurveda

and Other Traditional

Medicines

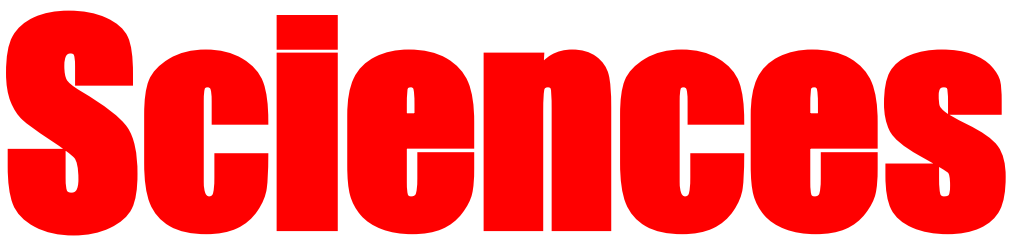

www.jayumedsci.com

ISSN 2456-4990

\title{
Do Ayurveda Need Studies on Drug Interactions - A Note
}

Often, consumers believe that traditional medicines are natural and safe that is not always true. In the current scenario, herbal products are increasingly being used as dietary supplements / nutraceuticals and such supplements are available over the counter for self-medication. As these products also contain some pharmacologically active compounds; likelihood of interactions is anticipated when used concomitantly. This is an important and underestimated area in therapeutics. Classics of Ayurveda considered this aspect and prescribed guidelines on compatible (pathya) and incompatible (apathya) diet (ahara) and deeds (vihara) while using traditional formulations, possibly considering herb-drug and / or herb-herb and / or herb-diet interactions. Exclusive instructions to avoid all such incompatible combinations have been emphasized. Unfortunately, evidences on herb-drug interactions on their concomitant use with prescribed drugs are meagre. In-vitro, in-vivo experiments to generate evidences in this direction may provide a few leads.

Aggarwal et al 


\section{Do Ayurveda Need Studies on Drug Interactions - A Note}

Punam Aggarwal, Poonam Gulati, Pramod Yadav, Galib Ruknuddin*, Pradeep Kumar Prajapati

Department of Rasa Shastra and Bhaishajya Kalpana, All India Institute of Ayurveda, Sarita Vihar, New Delhi 110076, India.

ARTICLE HISTORY Received 08.06.2018 Accepted 07.08.2018

CORRESPONDENCE Dr Galib R, Associate Professor, Department of Rasa Shastra and Bhaishajya Kalpana, All India Institute of Ayurveda, Sarita Vihar, New Delhi 110076, India. Email: galib14@yahoo.co.in

CITE THIS CONCEPT NOTE AS Aggarwal P, Gulati P, Yadav P, Ruknuddin G, Prajapati PK. Do Ayurveda Need Studies on Drug Interactions - A Note. J Ayu Med Sci 2018:3(2):347-50.

DOI 10.5530/jams.2018.3.14

Health is the level of metabolic efficiency of living organism. In human beings, it is the ability of individuals or communities to adapt and self-manage when facing physical, mental or social challenges. To maintain positive health; Ayurveda uses natural resources in the form of herbs, minerals, metals and other animal resources in the treatment. Among these, herbs are predominantly used since initial days of humanity for medical purposes and form the origin of much of modern pharmacotherapy. Based upon their significant contribution, herbal medicinal products have gained popularity in the past couple of decades ${ }^{[1]}$.

The resources have been classified as plant, animal, metal and mineral in origin ${ }^{[2]}$. These resources are converted into poly-herbal, herbo-mineral compound formulations that will be utilized in different pathologies. Comprehensive description pertaining to the origin of natural resources, their varieties, characteristics, processing techniques, properties, therapeutic uses, dietary regulations, possibilities of developing adverse effects and their management etc. is available in the texts of Ayurveda that is systematically arranged in respective classics.

Many consumers believe that herbal medicines are natural and therefore safe, but this is a dangerous over simplification $^{[3]}$. Some herbal medicines are associated with adverse effects, which include interactions with prescribed drugs ${ }^{[4]}$. A survey conducted in UK reported that $15 \%$ of patients receiving conventional pharmacotherapy also take herbal products and, among these, potential adverse herb-drug interactions were observed in $40 \%$ of patients ${ }^{[5]}$. A few reports are available on Garlic (Allium sativum L.), Ginkgo biloba L., St John's wort (Hypericum perforatum L.) etc. for their possible interactions with prescribed drugs ${ }^{[6-8]}$. Gugulipid, a fraction of Guggulu (Commiphora wightii (Arn.) Bhandari) has been found to significantly reduce peak plasma concentration and area under curve of diltiazem and propranolol in normal volunteers. Such interaction in patients receiving propranolol or diltiazem with gugulipid may lead to diminished efficacy or non-responsiveness due to significant reduction in bioavailability ${ }^{[9]}$. There is a potential herb-drug interaction between Aloe vera and Sevoflurane based on the anti-platelet effects ${ }^{[10]}$. Oral administration of glycyrrhizin increases the plasma prednisolone concentrations, suggesting that ingestion of licorice (fraction of Yashtimadhu) could interfere with corticosteroid treatment ${ }^{[11]}$. Such reports clearly show that all herbs are not safe in all conditions and herb-drug interactions are always possible, of which some are sufficiently serious to endanger the health of the consumers. It is therefore important to know about possible health hazards of concomitant use of herbs along with other prescribed drugs. Unfortunately, data on such possible interactions of traditional formulations with conventional drugs or interactions in between the traditional combinations is not available. Thus this area is unexplored and generating evidences in this direction is needed.

Interestingly, classics of Ayurveda prescribes guidelines on compatible (pathya) and incompatible (apathya) diet (ahara) and deeds (vihara) while using traditional formulations ${ }^{[12]}$. Such concepts might be explained by considering possibilities of dietherb and / or herb-herb interactions, thus emphasized on avoiding incompatible combinations of herbs, diet and deeds while consuming different formulations. A few such references are placed at Table 1 .

Over the past few decades, there has been growing global interest towards traditional formulations, thus scientific validation related aspects have been increasingly witnessed. Though, herbal pharmaceutical sector has developed and ample of advancements took place in terms of establishing standard monographs, evaluating safety profiles, proving clinical efficacy in 


\section{Compatible substances (Pathya)}

Mercurial preparations like Rasakarpura gutika (Rasa tarangini 6/84-86) and Rasaparpati (Rasa tarangini 6/154-161)

\section{Parada rasayana sevana (Rasa} tarangini 7/89-100)

\section{Gandhaka (Sulphur)}

(Rasa tarangini 8/66-93 and 109)

\section{Abhraka (Mica)}

(Rasa tarangini 10/74-116)

Suvarna bhasma (Calcined gold) -(Rasendra chintamani 14/25)

Loha (Calcined iron) (Rasendra chintamani 8/82-92)

Haratala (Arsenic trioxide)

(Ayurveda prakasha 2/188-192)

Shilajatu (Ashtanga sangraha Uttara 49/167)

Visha (Aconitum spe.) (Ayurveda prakasha 6/78-79)
Aahara: Navaneeta (butter) Narikelodaka (coconut water),

Kakavaha (Solanum nigrum Linn.), Patola (Trichosanthes dioica Roxb.), Pugaphala (Areca catechu Linn.), Ardraka (Zingiber officinale Roscoe.), Vastuka (Chenopodium album Linn.), Kadali prasuna (Inflorescence of Musa sapientum Linn.), Krishna vartaka (Solanum melongena Linn.), Go payah with Sharkara (cow milk with sugar)

Aahara: Shringvera (Zingiber officinale Roscoe.), Dhanyaka (Coriandrum sativum Linn.), Jeeraka (Cuminum cyminum Linn.), Vartaka (Solanum melongena Linn.), Patola (Trichosanthes dioica Roxb.), Tandula (Oryza sativa Linn.), Vastuka (Chenopodium album Linn.), Punarnava (Boerhavia diffusa Linn.), Go payah (cow milk), Dadhi (curd), Ghrita (clarified butter), Godhuma (Triticum sativum Lam.), Mudga (Phaseolus radiates Linn.)

Aahara: Shastikodana (Oryza sativa Linn.) + Dugdha sarkara (milk with sugar), Sheeta virya dravyas (substances that are cool in nature)

Vartaka (Solanum melongena Linn.), Patola (Trichosanthes dioica Roxb.), Brihati (Solanum indicum Linn.), Tanduliyaka (Amaranthus Spinosus Linn.), Dhanyaka (Coriandrum sativum Linn.), Punarnava (Boerhavia diffusa), Narikela (Cocos nucifera Linn.), Khajura (Phoenix sylvestris (L.) Roxb.), Dadima (Punica granatum Linn.), Pakva amra (ripened Mangifera indica Linn.), Draksha (Vitis vinifera Linn.), Tala phala (Borassus flabellifer Linn.), Lavanga (Syzygium aromaticum (L.) Merr.\& L.M Perry), Puga (Areca catechu Linn.), Tambula patra (leaf of Piper betel Linn.) etc. --

$-$

Ghrita (clarified butter), Ksheera (milk), Sita (sugar), Kshaudra (honey), Godhuma (Triticum sativum Lam.), Yava (Hordeum vulgare Linn.), Maricha (Piper nigrum Linn.), Saindhava (rock salt), Draksha (Vitis vinifera Linn.), Madhura dravya (sweet substances) etc.

\section{Incompatible substances (Apathya)}

Aahara: Amla dravya (sour substances), Ushna dravya (hot substances), Tikta dravya (herbs that are bitter in taste), Guda (jaggery)

Vihara: Shishira salila snana (bath with cold water), Shishira vatadi sevana (exposure to cold wind), Kopa (anger), Chinta (excessive thinking) etc.

Aahara: Madya (alcohol),

Kakaradi gana like Kushmanda (Benincasa hispida (Thunb.) Cogn.), Kulatha (Dolicos biflorus Linn.), Karkotaka (Momordica dioica Roxb. ex Willd.), Kapitha (Limonia acidissima Groff.)

Vihara: Salila krida (playing in water), Ati nidra (excessive sleep), Kopa (anger), Dukha (grief), Ati modam (excessive happiness) etc.

Aahara: Substances that are Kshara (alkaline), Amla (sour), Lavana (salty) etc.

Aahara: Karira (Capparis aphylla Roth.), Karavellaka (Momordica charantia Linn.), Amla kola (sour fruits of Zizyphus jujuba Lam.), Taila (oils), Kshara (alkaline substances), Vartaka (Solanum melongena Linn.)

Bilva phala (Aegle marmelos (L.) correa)

Lakucha (Artocarpus lakoocha Roxb.), Badara (Ziziphus jujuba Mill.), Jambeera (Citrus limon (L.) Osbeck), Tintidika (Tamarindus indica Linn.), Chanaka (Cicer arietinum Linn.), Karavelaka (Momordica charantia Linn.) etc.

Lavana (salt), substances that are predominant in Amla (sour) and Katu (pungent), excessive exposure to Vahni (fire) and Aatapa (sun-light).

Vyayama (exercise), exposure to Aatapa (sun light), Maruta (wind), Consumption of Guru (heavy), Vidahi (Spicy), Kulattha (Dolichos biflorus Linn.), Kakmachi (Solanum nigrum Linn.) and meat of Kapota (pigeon) -- 
different pathologies; drug interactions is an area that is emerging in recent times and need to be addressed appropriately.

Drug interactions can be defined as the modification of the safety and efficacy profile of a medication following the coadministration of drugs, ingredients or additives present in the $\operatorname{diet}^{[13]}$. When herbs are associated with such interactions, the situation is known as herb-drug interactions. Although there is a widespread public perception that herbs and dietary supplements are safe, researches have demonstrated that these products carry the same dangers as other pharmacologically active compounds. In the current scenario, plant derived products are increasingly being accepted as nutraceuticals and dietary supplements and are available over the counter for self-medication ${ }^{[14]}$. Interactions may occur between prescription drugs, over-the-counter drugs, dietary supplements, and foods making it a daunting challenge to identify all interactions that are of clinical concern ${ }^{[15]}$.

It has been clearly stated in the classics that, the substances antagonistic to the body tissues are harmful and one has to be cautious while using such substances. Incompatible substances, on administration are capable of interacting with each other, vitiates blood (shonita pradooshanam) and causes obstruction to the channels (srotas) of the body. Such vitiated blood and obstructed channels (altered functioning) will further settle down in different pathologies and at times may lead to death. This concept is discussed under the heading of Viruddhain the classics ${ }^{[16]}$.

Though, a mechanism was implemented by Govt. of India to monitor ADR through Pharmacovigilance program for Ayurveda, Siddha, Unani drugs ${ }^{[17]}$; reporting of drug related inconveniences like adverse effects etc. appear to be less frequent. The consumers, physicians and administrators have to be aware towards such manifestations and possibilities of interactions on concomitant use of prescribed drugs.

Safety has always been prioritized in Ayurveda. A medicine that develops adverse events while treating a disease is considered as Ashuddha (improper) ${ }^{[18]}$. Ayurveda has its own way of diagnosis and treatment. Classics cautioned against unnecessary usage of medicines that may lead to adverse events $^{[19]}$. In addition, strict restrictions with special emphasis on what to eat and what to avoid etc. have been meticulously been imposed in the classics. Non-compliance of all such restrictions will lead to risk of adverse events or drug interactions at times.

It has been stated in the classics that the use of incompatible drugs can culminate into disease, temporary or permanent damage to structure and function of the organs or even death ${ }^{[20]}$. Specific Bhavana dravyas (processing media) have been advocated while preparing different formulations. For example; while preparing Tribhuvanakirti rasa, the powdered blend of raw material is to be sequentially levigated with juices of Tulasi (Oscimum sanctum Linn.), Ardraka (Zinziber officinalis Roscoe.) and Dhatura (Dhatura metal Linn. $)^{[21]}$.

Great care has been laid down while using different drugs in therapeutics ${ }^{[22]}$. Drug selection, dose and their administration should be judicious. They should mandatorily be prescribed along with the specified adjuvants like ghee, milk, honey etc. Emphasis has been laid on Anupana / Sahapana like ghee, milk, honey etc. while administering traditional formulations. For example; Mrityunjaya rasa is to be administered along with honey ${ }^{[23]}$. In absence of suitable Anupana / Sahapana, adverse reactions are likely. Table 2 gives a view on such Anupana / Sahapana explained in Anupana Manjari. Besides Anupana, exclusive regulations in terms of Ahara (diet) and Vihara (deeds) have also been imposed during the treatment period, as briefed at Table - 1. It infers that, the adjuvants and diet have a definite role on efficacy profile of prescribed drugs.

Table 2. Anupana / Sahapana to be followed while using Metallic formulations (Bhasma)

\begin{tabular}{|c|c|c|}
\hline Bhasma & Anupana / Sahapana & Reference \\
\hline Suvarna & $\begin{array}{l}\text { Haritaki (Terminalia chebula } \\
\text { Retz.) with Sita }\end{array}$ & $\begin{array}{l}\text { Anupana } \\
\text { Manjari 1/4 }\end{array}$ \\
\hline Tamra & $\begin{array}{l}\text { Agstya (Sesbania grandiflora L. } \\
\text { Pers.) with Sita }\end{array}$ & $\begin{array}{l}\text { Anupana } \\
\text { Manjari } 1 / 6\end{array}$ \\
\hline Naga & $\begin{array}{l}\text { Haritaki (Terminalia chebula } \\
\text { Retz.) with Sita }\end{array}$ & $\begin{array}{l}\text { Anupana } \\
\text { Manjari 1/7 }\end{array}$ \\
\hline Vanga & $\begin{array}{l}\text { Meshasringi (Dolichandrone } \\
\text { falcate Wall ex DC. Seem.) with } \\
\text { Sita }\end{array}$ & $\begin{array}{l}\text { Anupana } \\
\text { Manjari 1/8 }\end{array}$ \\
\hline Haratala & $\begin{array}{l}\text { Jiraka (Cuminum cyminum L.) } \\
\text { with Sharkara }\end{array}$ & $\begin{array}{l}\text { Anupana } \\
\text { Manjari 2/7-8 }\end{array}$ \\
\hline Manahshila & $\begin{array}{l}\text { Jiraka (Cuminum cyminum L.) } \\
\text { with Makshika }\end{array}$ & $\begin{array}{l}\text { Anupana } \\
\text { Manjari 2/11 }\end{array}$ \\
\hline Abhraka & Amalaki (Phyllanthus emblica L.) & $\begin{array}{l}\text { Anupana } \\
\text { Manjari 2/13 }\end{array}$ \\
\hline Parada & $\begin{array}{l}\text { Gandhaka with Nagavalli (Piper } \\
\text { betel Linn.) }\end{array}$ & $\begin{array}{l}\text { Anupana } \\
\text { Manjari 2/1-2 }\end{array}$ \\
\hline Raskarpura & $\begin{array}{l}\text { Dhanyaka (Coriandrum sativum } \\
\text { L.) with Sita }\end{array}$ & $\begin{array}{l}\text { Anupana } \\
\text { Manjari 2/18 }\end{array}$ \\
\hline
\end{tabular}

Herbal formulations as potential source of therapeutics has attained a significant role in health system all over the world not only in the diseased condition but also as useful material in maintaining health. Though, significant achievements have been made in the herbal drug industry; evidences on the interaction of potential herbs with drugs on their concomitant use has not yet been available. Attempts should be made to generate evidences based on in-vitro, in-vivo experiments. 


\section{SOURCE OF SUPPORT Nil}

CONFLICT OF INTEREST Authors declare no conflict of Interest

CONTRIBUTORS Dr. Punam Aggarwal and Dr. Poonam Gulati contributed to literature study and data acquisition. Dr. Pramod Yadav, Dr. Prajapati PK contributed to the conceptualization of the topic. Dr. Galib contributed to the manuscript review, analysis, design and literature study.

\section{REFERENCES}

1. Bent S. Herbal medicine in the United States: review of efficacy, safety, and regulation. Grand rounds at University of California, San Francisco Medical Center. J Gen Intern Med 2008;23(6):854-9.

2. Agnivesha. In: Vaidya Yadavji Trikamji Acharya editor. Charaka Samhita. Varanasi: Chaukhamba Surbharati Prakashan;2014; p.20.

3. Agnivesha. In: Vaidya Yadavji Trikamji Acharya editor. Charaka Samhita. Varanasi: Chaukhamba Surbharati Prakashan;2014; p.23.

4. Ulbricht C, Chao W, Costa D, Rusie-Seamon E, Weissner W, Woods J.. Clinical evidence of herb-drug interactions: a systematic review by the natural standard research collaboration. Curr Drug Metab 2008;9(10):1063-120.

5. Bush TM, Rayburn KS, Holloway SW, Sanchez-Yamamoto DS, Allen BL, Lam T. Adverse interactions between herbal and dietary substances and prescription medications: a clinical survey. Altern Ther Health Med 2007;13(2):30-5.

6. Borrelli F, Capasso R, Izzo AA. Garlic (Allium sativum L.): adverse effects and drug interactions in humans. Mol Nutr Food Res 2007;51(11):1386-97.

7. Ernst E, Canter PH, Coon JT. Does Ginkgo biloba increase the risk of bleeding? A systemic review of case reports. Perfusion 2005;18:52-6.

8. Mills E, Montori VM, Wu P, Desai NK, Kshirsagar NA, Gupta KC Interaction of St John's wort with conventional drugs: systematic review of clinical trials. BMJ 2004;329:27-30.

9. Dalvi SS, Nayak VK, Pohujani SM, et. al. Effect of gugulipid on bioavailability of diltiazem and propranolol. J Assoc Physicians India 1994;42(6):454-5.
10. Lee A, Chui PT, Aun CS, Gin T, Laus AS. Possible interaction between sevoflurane and Aloe vera. Ann Pharmacother 2004;38(10):1651-4.

11. Chen MF, Shimada F, Kato H, et.al. Effect of oral administration of glycyrrhizin on the pharmacokinetics of prednisolone. Endocrinol Jpn. 1991;38(2):167-74.

12. Vriddha Jeevaka. In: Pandit Hemraj Sharma editor. Kashyapa Samhita. Varanasi: Chaukhambha Sanskrit Sansthan; 2015; p.370.

13. sciencedirect.com. Drug interactions; c2018 [cited at 15:24 on 09:06:2018] Available from https://www.sciencedirect.com/topics/pharmacology-toxicology-andpharmaceutical-science/drug-interaction.

14. Robert H, Poppenga DVM. Risk Associated with the Use of Herbs and Other Dietary Supplements. Veterinary Clinics of North America: Equine Practice. 200;17(3):455-77.

15. nccih.nih.gov. Drug interactions: c2018 [cited at 15:29 on 09:06:2018] Available from https://nccih.nih.gov/health/providers/digest/herbdrug.

16. Agnivesha. In: Vaidya Yadavji Trikamji Acharya editor. Charaka Samhita. Varanasi: Chaukhamba Surbharati Prakashan;2014; p.14951.

17. Chaudhary A, Singh N, Kumar N. Pharmacovigilance: Boon for the safety and efficacy of Ayuvedic formulations. Journal of Ayurveda and Integrative Medicine. 2010;1(4):251-256.

18. Agnivesha. In: Vaidya Yadavji Trikamji Acharya editor. Charaka Samhita. Varanasi: Chaukhamba Surbharati Prakashan;2014; p.228.

19. Vriddha Jeevaka. In: Pandit Hemraj Sharma editor. Kashyapa Samhita. Varanasi: Chaukhambha Sanskrit Sansthan;2015; p.375.

20. Sri Dalhanacharya. In: Vaidya Yadavji Trikamji Acharya editor. Susruta Samhita. Varanasi: Chaukhamba Surbharati Prakashan;2014; p.94.

21. Govind Das. In: Prof. Siddhi Nandan Mishra editor. Bhaishajya Ratnavalai. Varanasi: Chaukhamba Surbharati Prakashan;2014; p.177.

22. Agnivesha. In: Vaidya Yadavji Trikamji Acharya editor. Charaka Samhita. Varanasi: Chaukhamba Surbharati Prakashan;2014; p.484.

23. Gopal Krishna. In: Vaidya Satyarth Prakash editor. Rasendra sara sangraha. Varanasi: Krishnadas Academy;1994; p.230. 